\title{
UTILIZATION OF SELECTED ELECTRONIC MASS MEDIA AS SOURCES OF AGRICULTURAL INFORMATION BY FARMERS IN NORTHERN TARABA STATE, NIGERIA
}

\author{
A0 $\mathrm{Ani}^{1}$ and SA Baba ${ }^{2}$ \\ ${ }^{1}$ Department of Agricultural Economics and Extension, University of Maiduguri, Nigeria \\ ${ }^{2}$ Department of Agricultural Education, Taraba State College of Education, Jalingo, Nigeria
}

Accepted: $16^{\text {th }}$ May 2009

\begin{abstract}
This study was on utilization of selected electronic mass media as sources of agricultural information by farmers in Northern part of Taraba state of Nigeria. The study considered among others the socioeconomic characteristics of the respondents (farmers), the different electronic mass media utilized by the respondents and the major constraints associated with the utilization of electronic mass media in agricultural information delivery. Simple random sampling method was used in selecting 120 farmer respondents for this study. Questionnaires/interview schedules were administered to them. Similarly, questionnaires were administered to the programme managers of electronic mass media outfits studied. Percentages, frequencies and regression analysis were used to analyse the data. The major findings among others include that among the electronic mass media studied, radio was the most utilized by the respondents, and that farm income, age, educational level and farming experience of the respondents had positive coefficients and significant relationship with the utilization of electronic mass media organs. It is suggested among others that there should be provisions of digital electronics gadgets to meet with the recent development in technologies in agricultural information dissemination.
\end{abstract}

Key words: Agricultural information, Farmers, Northern Taraba state, Technology, Utilization electronic mass media

\section{INTRODUCTION}

Information and communication are essential ingredients needed for effective transfer of technologies that are designed to boost agricultural production. For farmers to benefit from such technologies, they must first have assess to them and learn how to effectively utilize them in their farming systems and practices. This should be the function of agricultural extension agencies all over the world. These extension agencies make use of different approaches, means and media in transferring improved agricultural technologies to the end users (farmers).

Mass media methods in agricultural information dissemination generally, are useful in reaching a wide audience at a very fast rate. They are useful as sources of agricultural information to farmers and as well constitute methods of notifying farmers of new developments and emergencies. They could equally be important in stimulating farmers' interest in new ideas and practices (Ani et al. 1997). To a large extent, mass media serve as a veritable instrument for information dissemination in agriculture.

Agricultural extension/information delivery is precisely a process of communication of improved skills, practices, innovations, technologies and knowledge to farmers. Thus, agricultural extension is a service which helps or assists people, particularly farm families through educational procedures in promoting their farming practices and techniques, increasing their production efficiency and income, bettering their levels of living and lifting their social, economic and educational standards of rural life (Ogunbameru 2001). Food and Agricultural Organisation (FAO 2001) reported that in many developing countries, wide adoption of research results by majority of farmers remains quite limited. This therefore, calls for a system which allows adequate information flow from researchers to farmers and vice-versa. Hence, Agricultural extension agencies have central role in facilitating the flow of a variety of information to offer the needed exposure of farmer to innovation for overall development.

In spite of the agrarian nature of Taraba State in Nigeria, few agricultural programmes are featured in the available electronic media outfits in the state (Programme Schedule 2004). Similarly, it has been observed that the Taraba Agricultural Development Programme (TADP) used few print and electronic mass media methods in its operations (Baba 2006). This could be due to financial and bureaucratic bottlenecks or that farmers are not fully aware of the operations of the electronic mass media outfits. It is against this background that this study was undertaken to assess the utilization of 
selected electronic mass media by farmers as sources of Agricultural information in Northern part of Taraba State, Nigeria. The specific objectives of the study were to:

- Identify the socio-economic characteristics of the farmers studied

- Examine the different electronic mass media utilized by the farmers;

- Determine the relationship between utilization of electronic mass media and socio-economic characteristics of the farmers

- Identify major constraints associated with the utilization of electronic mass media in agricultural information delivery.

\section{METODOLOGY}

The study was conducted in the Northern part of Taraba state of Nigeria. This study used purposive sampling in selecting Ardo-kola and Jalingo Local Government Areas in Northern Taraba State. The choice of these two Local government areas was because they were the areas that had regular programmers /services of the electronic mass media stations in the state. The electronic mass media outfits studied include Nigerian Television Authority (NTA), Taraba State Broadcasting Service (TSBS) and Taraba Television (TTV) as well as Taraba Agricultural Development Programme (TADP), which is the organization with the mand ate of extension delivery service

Simple random sampling by balloting (assigning numbers and picking randomly) was used in selecting six agricultural wards from this area. In the wards selected, the number of farmers utilizing electronic mass media are as follows: 36 , 28, 34, 35, 30 and 27 for wards 1, 2, 3, 4, 5 and 6 respectively. Subsequently, twenty (20) farmers each were selected from these wards using the simple random sampling approach, thereby making the total number of farmer respondents to one hundred and twenty (120).

Questionnaires/Interview schedules were administered to respondents to elicit the required agricultural information. Interview schedules/ questionnaires were developed to explore farmers' socio-economic status and other necessary information. Similarly, questionnaires were administered on the Programme Managers of TADP and electronic mass media stations, i.e NTA, TSBS and $\mathrm{TTV}$, to determine their use towards agricultural extension delivery.

Descriptive and inferential statistics were employed for data analysis and interpretations. Percentages and frequencies were used to analyse the socio-demographic data of the respondents, while regression analysis was employed to ascertain the relationship between socio-economic characteristics of the respondents and the utilization of elec- tronic mass media as sources of agricultural information delivery.

\section{RESULTS AND DISCUSSION}

\section{Socio-Demographic Characteristics of Respon- dents}

The socio-demographic (characteristics) of the respondents were examined with respect to their sex, age, level of education, marital status and farming experience. Table 1 presents information on the sex distribution of the respondents It indicates that about $84 \%$ of the respondents were males $15.8 \%$ of them were females. This mean that males value more than females the importance of both agriculture and electronic mass media activities.

The data in Table 1 show that the respondents who were able bodied individuals constituted the majority of farmers $(73 \%)$, with age ranges of $21-$ 50 years. This could be due to the fact that agriculture in the study area was still of the subsistence type which demands much labour to be provided by able-bodied family members. However, for modem agricultural production, it requires effective and efficient channels of agricultural information which should cover all aspects of agricultural enterprise. This therefore, calls for adequate use of mass media which is very crucial in disseminating agricultural information to all people including the various age categories of rural farmers (Bununu and Udomisor 1997). The main thrust of mass media programmes as sources of agricultural information is to serve as stimuli to increased output.

The information contained in the table also reveals the educational qualifications of the respondents which presumably affected the utilization of mass media. About 35\% of the respondents had Ordinary National Diploma (OND) and or Nigerian Certificate in Education (NCE) as their highest educational qualification.

About $10 \%$ of the respondents had no formal education. The high percentage of OND and NCE holders in the study area may not be unconnected with the presence of tertiary educational institutions located in the study area - The Taraba State College of Agriculture and Education respectively. Farmers' education generally has been found to enhance production among food crop farmers, apparently resulting from their efficiency in using new production technologies (Ani 2006). Methods of using these new production technologies are demonstrated through the use of mass media.

Information on the marital status of the respondents are indicated on the Table 1 . Majority of respondents (70\%) were married. Adamu (2005) had reported that about $90 \%$ of Nigerian populations are engaged in agricultural production processes of 
various types regardless of their marital status. However, it could be deduced that since majority of the respondents were married, it is expected that the types of mass media used would be largely influenced by their spouses.

Data on farming experience of the respondents are shown on the Table 1 . The most plausible conclusion to be drawn from this result is that most of the respondents had farmed for a reasonable number of years as would enable them to be abreast with the use of most mass media as sources of agricultural information. The farming experience of farmers to a large extent affects their managerial know-how as well as the use of various extension methods including mass media methods (Ani 2002).

\section{Utilization of Electronic Mass Media by Farm- ers}

Table 2 presents information on sources of agricultural information available to the respondents. The data indicate that majority of farmers (53.3\%)

Table 1: Distribution of Socio-economic Characteristics of Respondents $(\mathrm{N}=120)$

\begin{tabular}{|c|c|c|}
\hline Variables & $\begin{array}{c}\text { Fre- } \\
\text { quency }\end{array}$ & Percentage \\
\hline \multicolumn{3}{|l|}{ Sex } \\
\hline Male & 101 & 84.2 \\
\hline Female & 19 & 15.8 \\
\hline \multicolumn{3}{|l|}{ Age(years) } \\
\hline Below 20 & 33 & 27.50 \\
\hline $21-30$ & 84 & 70.00 \\
\hline $31-40$ & 02 & 1.67 \\
\hline $41-50$ & 01 & 0.83 \\
\hline Above 50 & 04 & 3.30 \\
\hline \multicolumn{3}{|l|}{ Educational Level } \\
\hline No formal education & 12 & 10.00 \\
\hline Primary School Certificate & 14 & 11.70 \\
\hline Secondary School or Equivalence & 32 & 26.70 \\
\hline $\mathrm{OND} / \mathrm{NCE}$ & 42 & 35.00 \\
\hline University Degree/equivalence & 20 & 16.70 \\
\hline \multicolumn{3}{|l|}{ Marital Status } \\
\hline Single & 33 & 27.50 \\
\hline Married & 84 & 70.00 \\
\hline Widowed & 02 & 1.67 \\
\hline Divorced & 01 & 0.83 \\
\hline \multicolumn{3}{|l|}{ Farming Experience (years) } \\
\hline Less than 5 & 07 & 5.80 \\
\hline $5-10$ & 23 & 19.20 \\
\hline $11-15$ & 46 & 38.40 \\
\hline $16-20$ & 28 & 23.30 \\
\hline Above 20 & 16 & 13.30 \\
\hline \multicolumn{3}{|l|}{ Farmer's income } \\
\hline Less than $\mathrm{N} 10,000$ & 07 & 5.8 \\
\hline $\mathrm{N} 11,000-\mathrm{N} 20,000$ & 23 & 19.2 \\
\hline $\mathrm{N} 21,000-\mathrm{N} 30,000$ & 18 & 15.0 \\
\hline $\mathrm{N} 31,000-\mathrm{N} 40,000$ & 28 & 23.3 \\
\hline Above N40, 000 & 44 & 36.6 \\
\hline
\end{tabular}

sourced their agricultural information from radio. This aggresses with Ani (2004); Buba (2003); Fadama (2005) and Ogunbameru (2001) who expressed that radio cuts across the literacy barriers required in books, newspapers, journals, bulletins, pamphlets etc. Radio in essence often does not require higher educational qualification or background to be effective. Even the pastoralists who are often physically inaccessible (to many other electronic media) and who live in low population densities can be mobilized at the same time with radio anywhere without necessarily interfering with their daily activities at homes or in fields.

The table 2 also shows that about $22 \%$ of the respondents got their agricultural information from extension agents through Taraba State Agricultural Development Programme (TADP) while about $20 \%$ of the respondents got their information through television. The neighbours - friends - relations served as source of information to only about $4.2 \%$ of the respondents. This agrees with Muhammad and Garforth (2001) findings that interpersonal communication among farmers was extremely lacking and radio was the major source followed by television. In this study, electronic mass media appeared relatively more popular than the direct contact method of communication among farmers.

Information contained in the Table 3 shows most popular agricultural programmes in electronic media as utilized by the respondents. The table indicates that Food Basket of the NTA and Noma Tsohon Ciniki of the TSBS had $21.2 \%$ of the respondents each who attested to the fact that the most popular agricultural programmes they enjoyed came from these media organs. About $20.3 \%$ of the respondents indicated that their most popular agricultural programme came from Fadama II which was aired by TSBS, while $14.8 \%$ of the respondents pointed out that their own most cherished programme came from Noma Fadama by TTV. Similarly, $9.7 \%, 8.8 \%$ and $4.2 \%$ of the respondents mentioned Noma Tushen Arziki by TTV, Wildlife Network by NTA and Wildlife Network Local by NTA respectively as the programmes that were more important to them.

These results show that television as an electronic medium is more utilized than others in disseminating agricultural information. Nwachukwu and Odoemelam (2004) had found in their study that television viewing in developing countries is growing rapidly and has great scope for timely research and action. Generally, electronic mass media can motivate, stimulate, sell ideas, induce belief, create and change attitudes positively. 
Table 2: Sources of Agricultural Information for Farmers

\begin{tabular}{lll}
\hline Sources of Information & Frequency & Percentage \\
\hline Extension Agent/TADP & 27 & 22.5 \\
Television & 24 & 20.0 \\
Neighbours, Friends and Rela- & 5 & 4.2 \\
tions(NFRS) & \\
Radio & 64 & 53.3 \\
\hline
\end{tabular}

Relationship Between Utilization of Electronic Mass Media and Socio-economic Characteristics of the Respondents

Table 4 contains information on regression analysis of socio-economic variables influencing utilization of electronic mass media organs as sources of agricultural information. The data indicate that farm income $\left(\mathrm{X}_{1}\right)$, age of respondents $\left(\mathrm{X}_{2}\right)$, educational level of the respondents $\left(X_{3}\right)$, and farming experience of the respondents $\left(\mathrm{X}_{5}\right)$ had positive coefficients and significant relationship with the utilization of electronic mass media organs as sources of agricultural information in the study area. This means that an increase in any of these variables would lead to increased utilization of the electronic mass media studied. The $X_{1}$ and $X_{3}$ variables are both significant at the $1 \%$ level, while $\mathrm{X}_{2} \mathrm{X}_{4}$ and $\mathrm{X}_{5}$ are relevant at $5 \%$ significant level.

These findings correspond to those of Baba (1995) Ogunbameru (2001) and Abubakar (2003) who reported that relationships exist between socioeconomic characteristics of farmers and dependent variables. Various analyses by these authors showed relationship of socio-economic factors such as age of farmers, level of formal education, and accessibility of credit facilities, household size, farm size and farm income of farmers, which were found to be significant to the overall performances of farm businesses. The significance and positiveness of some of these explanatory variables (income, age, educational level and farming experience) could be due to the influence of extension services and other predictor variables. Increased

Table 3: Most Popular Agricultural Programmes in Electronic media

\begin{tabular}{lll}
\hline Agricultural Programme & Frequency & Percentage \\
\hline Food basket (NTA) & 46 & 21.2 \\
Noma Tsohon Ciniki (TSBS) & 46 & 21.2 \\
Fadama II (TSBS) & 44 & 20.3 \\
Noman Fadama (TTV) & 32 & 14.8 \\
Noma Tushen Arziki (TTVS) & 21 & 9.7 \\
Wildlife Network (NTA) & 19 & 8.8 \\
Wildlife Local(NTA) & 09 & 4.2 \\
\hline
\end{tabular}

extension services to farmers could increase farmers' exposure to electronic mass media as sources of agricultural information. The implication therefore, is that the higher the level or status of farmers' education the more the utilization of electronic mass media organs as sources of agricultural information.

Household size $\left(\mathrm{X}_{4}\right)$ is negative in its coefficient, but statistically significant at 5\% level. This could mean that the higher the household size, the less the utilization of electronic mass media and vice versa. This largely could be attributed to the expenses on the part of the farmers in the training and educating their children in formal schooling which substantially could limit their affordability of electronic mass media.

However, the coefficient of determination (R2) is 0.553 . This means that all the selected independent variables included for the regression analysis explained $55.3 \%$ of the variation of the use of electronic mass media by the respondents. This therefore, indicates that these variables - income, age educational level, household size and farming experience could be good predictors and determinants of the use of electronic mass media by farmers as sources of agricultural information

\section{Factors Against Effective Utilization of Elec- tronic Mass Media Stations}

Information contained in Table 5 present data on factors that militate against effective utilization of electronic mass media as sources of agricultural information in Taraba State of Nigeria. The four programme managers of the media stations studied-TTV, TSBS, NTA and TADP provided information on the factors hindering their optimum performance.

The Table 5 shows that all the stations in the state complained and accepted that power supply from Power Holding Company of Nigeria (PHCN) and insufficient funding are the major factors hindering the efficiency and utilization of electronic mass media stations. The media organs - TADP and NTA both cried out on the inadequacy of machine, equipment and gadgets as stumbling blocks

Table 4: Regression Analysis of Selected Socioeconomic Characteristics of Respondents

\begin{tabular}{llcl}
\hline Variables & Coefficients & $\begin{array}{l}\text { Standard t-value } \\
\text { error }\end{array}$ \\
\hline Income $\left(\mathrm{X}_{1}\right)$ & 0.355 & 0.059 & $6.030^{*}$ \\
Age $\left(\mathrm{X}_{2}\right)$ & 0.229 & 0.125 & $1.837^{* *}$ \\
Educational level $\left(\mathrm{X}_{3}\right)$ & 0.369 & 0.085 & $3.922^{*}$ \\
Household size $\left(\mathrm{X}_{4}\right)$ & -0.121 & 0.065 & \\
Farming experience $\left(\mathrm{X}_{5}\right)$ & $9.100 \mathrm{E}-02$ & 0.054 & - \\
Constant & -1.558 & & $1.861^{* *}$ \\
R-squared $\left(\mathrm{R}^{2}\right)$ & 0.553 & \multicolumn{1}{c}{1.691} \\
\hline Key: Significant at 1\% level & \multicolumn{3}{c}{ Significant at 5\% level }
\end{tabular}


to electronic mass media utilization in the state. Similarly, TSBS also complained of this factor expressing that the new digital equipment are yet to be fully installed and utilized. However, only TTV indicated low income status of the audience as a major factor influencing the utilization of electronic mass media in the study area. This could be largely attributed to high cost of television sets which is beyond the reach of a greater proportion of the audience.

The farmer respondents in their separate opinions affirmed most of the points as indicated above. Many of them pointed out that their low level of income could not allow them to afford these electronic mass media; therefore, they have little or no access to information on agriculture through these media. Added to this is that some of these farmers were not educated, consequently, they may not understand most agricultural information through electronic mass media.

\section{SUMMARY AND CONCLUSION}

This study was on assessment of selected electronic mass media as sources of agricultural information by farmers in northern part of Taraba State of Nigeria. The study has indicated that majority of the respondents (73\%) were able-bodied individuals who still had enough energy for meaningful agricultural production. These respondents got/sourced their agricultural information from radio (5 3.3\%), extension agents (22.5\%), television (20\%) and neighbour-friend-relations (4.2\%). The findings of the study also show that income, age of respondents, their educational level and farming experience had positive and significant relationship with the utilization of electronic mass media.

The findings of this study however, suggest that a greater proportion of the farmers in the study area needed the services and contributions of electronic mass media as sources of agricultural information. This will significantly help to generate and

Table 5: Factors Against Effective Utilization of Mass Media Stations

\begin{tabular}{|c|c|}
\hline $\begin{array}{c}\text { Name of Sta- } \\
\text { tion }\end{array}$ & Nature of Factors/Obstacles \\
\hline TTV & $\begin{array}{l}\text { a. Inadequate power supply } \\
\text { b. Low income level of the audience } \\
\text { c. Insufficient funding }\end{array}$ \\
\hline TSBS & $\begin{array}{l}\text { a. Inadequate power supply } \\
\text { b. Inadequate machines/equipment } \\
\text { c. Insufficient funding }\end{array}$ \\
\hline NTA & $\begin{array}{l}\text { a. Inadequate power supply } \\
\text { b. Inadequate machines/equipment/gadgets } \\
\text { c. Insufficient funding }\end{array}$ \\
\hline TADP & $\begin{array}{l}\text { a. Inadequate power supply } \\
\text { b. Inadequate machines/equipment gadgets } \\
\text { c. Insufficient funding }\end{array}$ \\
\hline
\end{tabular}

utilize most recent agricultural technologies that will boost agricultural production. This by implication would improve farmers' output and consequently their standard of living. However, the poor power supply to these electronic mass media outfits in the study area could be a big handicap to their effective utilization by farmers. Therefore, it is suggested that power supply from Power Holding Company of Nigeria (PHCN) should be improved significantly if meaningful results are to be expected. It is also necessary that there should be provision of digital electronic gadgets to meet with the recent development in technologies in agricultural information dissemination. This undoubtedly will aid electronic media functions as sources of agricultural information to farmers to cope with the increasing demand of information for improved agricultural production.

\section{REFERENCES}

Abubakar I 2003 Efficiency of yam production in Taraba State, Nigeria. Unpublished M.Sc. Dessertation, Department of Agricultureal Economics and Extension, University of Maiduguri, Nigeria, pp. $43-45$

Adamu B 2005 Daily Trust Newspapers, Kaduna, Nigeria, pp. 20-22.

Ani AO 2004 Factors inhibiting agricultural production among rural women in Southern Ebonyi State, Nigeria, Ph.D. Thesis, University of Maiduguri, Nigeria, p. 93.

Ani AO 2004 Women in Agriculture and Rural Development, Priscaquilla Publishers, p 84.

Ani A0 2006 Potential of oasis for sustainable agricultural production in Yobe State, Nigeria, International Journal of Agricultural and Biological Sciences, 43 (1): 1-5.

Ani A0, Undiandeye UC and Anogie DA 1997 The role of mass media in agricultural information in Nigeria, Educational forum, 3 (1): $80-85$.

Baba SA 1995 Economic analysis of beef cattle production in Jalingo Local Government Area of Taraba State, Nigeria, unpublished B. Sc. project, Department of Agricultural Economics and Extension, University of Maiduguri, Nigeria. Pp. $41-45$.

Baba SA 2006 Utilization of selected electronic mass media as sources of agricultural information by farmers in Northern part of Taraba State, Nigeria, Departmental Seminar, Department of Agric. Economics and Extension, University of Maiduguri, 67p.

Buba MB 2003 Introduction to nomadic education studies, Education and Management Services, Yola, Adamawa State, Nigeria, PP 120-121.

Bununu UI and Udomisor IW 1997 Educating the rural farmers through the television medium: A study of Mass farmers in Bauchi State, Nigeria, 
Educational forum, 3(1): 100-109.

Fadama 2005 Mobilizing and organizing community-driven development: Introduction and general principles, paper presentation series, Abuja, Nigeria.

FAO 2001 Reports of Food and Agricultural Organization of the United Nations, International Journal ofAgriculture and Biology, 3 (1): 222.

Muhammad S and Garforth C 2001 Farmer information sources and their relative effectiveness, International Journal of Agriculture and Biology, 3 (1): $223-225$.
Nwachukwu I and Odoemelam LC 2004 Effectiveness of television farm broadcast in the transfer of technology to farmers in Abia State, A paper presented at the 9th Annual Conference of AESON, Ile-Ife, Nigeria, p. 3.

Ogunbameru B0 2001 Practical Agricultural Communication, Graphic Publishers, Nigeria, pp. 13 -14 .

Programme Schedules 2004 Programme Schedule Second Quarter, NTA Channel 6, Jalingo, Publications, Taraba State, Nigeria 